\title{
New paleomagnetic results of upper Permian - lower Triassic volcanic sequences from the Hoa Binh area, northwest Vietnam
}

Cung Thuong Chi ${ }^{1}$, John W. Geissman ${ }^{2}$, Hoang Van Quy ${ }^{1}$, Nguyen Thi Phuong Dung ${ }^{1}$, Nguyen Thi Hoc ${ }^{1}$

${ }^{1}$ Institute of Geological Sciences, Vietnam Academy of Science and Technology

${ }^{2}$ Department of Geosciences, University of Texas at Dallas, ROC 21, 800 West Campbell Road, Richardson, Texas 75080-3021, USA

Accepted 25 December 2014

\begin{abstract}
Oriented-core samples (125) from twelve sites collected from the Late Permian-Early Triassic volcanic Vien Nam formation exposed at the Hoa Binh Dam area, northwest Vietnam yield interpretable magnetizations in progressive demagnetization. The characteristic remanent magnetization (ChRM) components carried by magnetite and hematite are successfully isolated from secondary components and reveal a mean, in situ (geographic coordinates) paleomagnetic direction of Decl. $=33.8^{\circ}$, Incl. $=-28.4^{\circ}$ $\left(\alpha_{95}=9.5^{\circ}, \mathrm{k}=30.3, \mathrm{~N}=9\right.$ site mean directions), corresponding to a virtual geomagnetic pole located at $\lambda=41.1^{\circ} \mathrm{N}, \phi=239.8^{\circ} \mathrm{E}$ and a paleo-latitude for the study area situated at $\sim 15{ }^{\circ} \mathrm{S}$ during the Late Permian to Early Triassic. A comparison of the pole we report in this study with the Late Permian-Early Triassic part of the South China Block apparent polar wander path shows that this volcanic terrane of northwest Vietnam has been close to if not a coherent part of the South China Block since the Late Permian. This result implies that insignificant cumulative displacement has occurred along the Ailao Shan/Red River fault system during the Cenozoic India-Eurasia collision.
\end{abstract}

(C) 2014 Vietnam Academy of Science and Technology

\section{Introduction}

Southeast Asia consists of a complex assemblage of Gondwana-derived continental blocks that were rifted from northern Gondwana and were translated northward during the closing of the Paleo-Tethys, Meso-Tethys and Neo-Tethys oceans. These continental blocks/terranes were sequentially amalgamated to form Southeast Asia during the Late Palaeozoic to Cenozoic (Sengor, 1979; Hutchison, 1989; Metcalfe, 2011). These terranes were periodically deformed during the process of constructing Southeast Asia in multiple collision events and plate reorganizations and

*Corresponding author, Email: chicung@gmail.com interactions (Fig. 1), resulting in the formation of strike-slip faults and attending rotations of crustal to lithosphere scale blocks in the process.

During the last twenty years, many paleomagnetic results from studies of Paleozoic to Mesozoic rock formations exposed in the South China block have been reported by different workers and these data enable the construction of an Apparent Polar Wander Path (APWP) for the South China Block and serve to define the approximate paleo-latitude and orientation of this block during the Permian. However, there are few paleomagnetic studies on Permian-Triassic rock formations from the Indochina Block, lying southwest of the South China Block (Achache and Courtillot, 1985; Chen and Courtillot, 1989; Yang 
Cung Thuong Chi, et al./Vietnam Journal of Earth Sciences 36 (2014)

and Besse, 1993), especially from the Vietnam region (Cung et al., 2000a). In this paper, we report new paleomagnetic results collected from Upper Permian - Lower Triassic volcanic rocks of the Vien Nam Formation from Hoa Binh area in northwest Vietnam. These new data confirm previous suggestions that components of Indochina in northern Vietnam lay at equatorial positions during the late Permian.

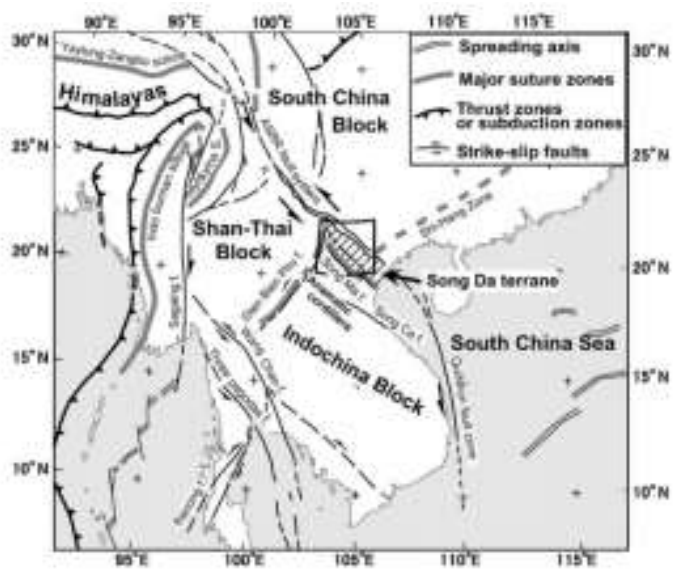

Figure 1. Tectonic framework map of Southeast Asia, modified from Leloup et al. (2001) and Takemoto et al. (2005). Arrows adjacent to several major structures show overall sense of shear prior to $\sim 16 \mathrm{Ma}$ along these structures. Enlargement of the blacked area is shown in Fig. 2

\section{Geologic/tectonic setting and sampling area}

Upper Permian - Lower Triassic volcanic rocks constitute much of the uppermost crust of northwest Vietnam, mainly within the Song Da rift basin located northeast of the Song Ma Suture Zone, which forms the boundary between the South China Block and the Indochina Block (Fig. 2). Permian basalts within the Song Da rift have yielded isotopic age determinations of $257-270$ Ma (Polyakov et al., 1999; Tran Trong Hoa, 1996; Hanski et al., 2004) and have been considered distal equivalents of the Emeishan rift basalts; the geochemistry of these basalts and associated Permian-Triassic komatiites suggests a plume related source (Hanski et al., 2004; Zhou et al., 2008). On the other hand, Lepvrier et al. (2004, 2008) suggest that the Permian basalts exposed north of the Song Ma Suture Zone (within Song Da rift basin) could have been emplaced in a backarc continental setting associated with a north- dipping oceanic subduction system involving Indochina crustal elements beneath South China, yet a corresponding calc-alkaline magmatic arc of that age is not well documented. Some authors suggest that Indochina and South China were separated by oceanic crust in the Late Permian to Early-Middle Triassic and that they collided during the Indosinian Orogeny in the Late Triassic (Zhang et al., 2006; Zhang and Cai, 2009; Cai and Zhang, 2009).

Permian flood basalts and associated maficultramafic intrusive rocks form a narrow NWtrending belt in the Song Da rift terrane. The belt is bounded by the Red River Fault zone to the northeast and the Song Ma suture to the southwest. The flood basalts unconformably overlie early Permian limestones, and are concordantly overlain by lower Triassic limestone and shale (Glotov et al., 2001). Folded Triassic sedimentary rocks are unconformably overlain by Cretaceous conglomerates, sandstones and pelites (Lacassin et al., 1998).

The Vien Nam Formation (Phan $\mathrm{Cu}$ Tien, 1977) is widely distributed within the Song Da rift terrane, from the Vien Nam area - Ba Vi extending through Kim Boi (Hoa Binh) to Van Yen, Ta Khoa and Nam So (Son La) areas in northwest Vietnam. Tran Trong Hoa (2001) describes the extrusive rocks of Vien Nam Formation as belonging to a combination of basalt (trachybasalt) trachyandesite - trachydacite, which are subalkaline basalts with high $\mathrm{Ti}$ and high alkaline compositions. Based on isotopic age determinations (Polyakov et al., 1999; Tran Trong Hoa, 1996; Hanski et al., 2004), the age of the mafic rocks remains imprecisely determined but is interpreted to be between about $257 \pm 24 \mathrm{Ma}$ and $270 \pm 15 \mathrm{Ma}$, corresponding to the Late Permian Early Triassic, and workers infer these rocks to be coeval with the Emeishan basalts exposed in South China.

In Vietnam, initial paleomagnetic work on these basalts was carried out by Cung (1996), who collected in the Hoa Binh and Son La areas. Renewed sampling was carried out by the authors in northwest Vietnam in 2013 and efforts were concentrated on Upper Permian to Lower Triassic volcanic rock sequences that crop out from Hoa Binh to Lai Chau province near the border with the People's Republic of China. Independently 
Vietnam Journal of Earth Sciences 36 (2014) 413-423

oriented samples (as drilled cores) were collected from numerous localities, and these were and continue to be analyzed in the Paleomagnetism Laboratory at the University of Texas at Dallas, USA. In this paper, only the paleomagnetic results obtained from basaltic rocks at Hoa Binh locality are presented; twelve sites with 125 core samples were collected from basaltic andesite and spilitic basalts of the Vien Nam Formation that wellexposed on both banks of the Da River, next to the Hoa Binh hydropower dam. Surface exposures of the volcanic rocks are largely massive in character, with little obvious field evidence of flow bedding or contacts between individual flow units. We note that in this general area, underlying Permian carbonate rocks are generally flat lying.

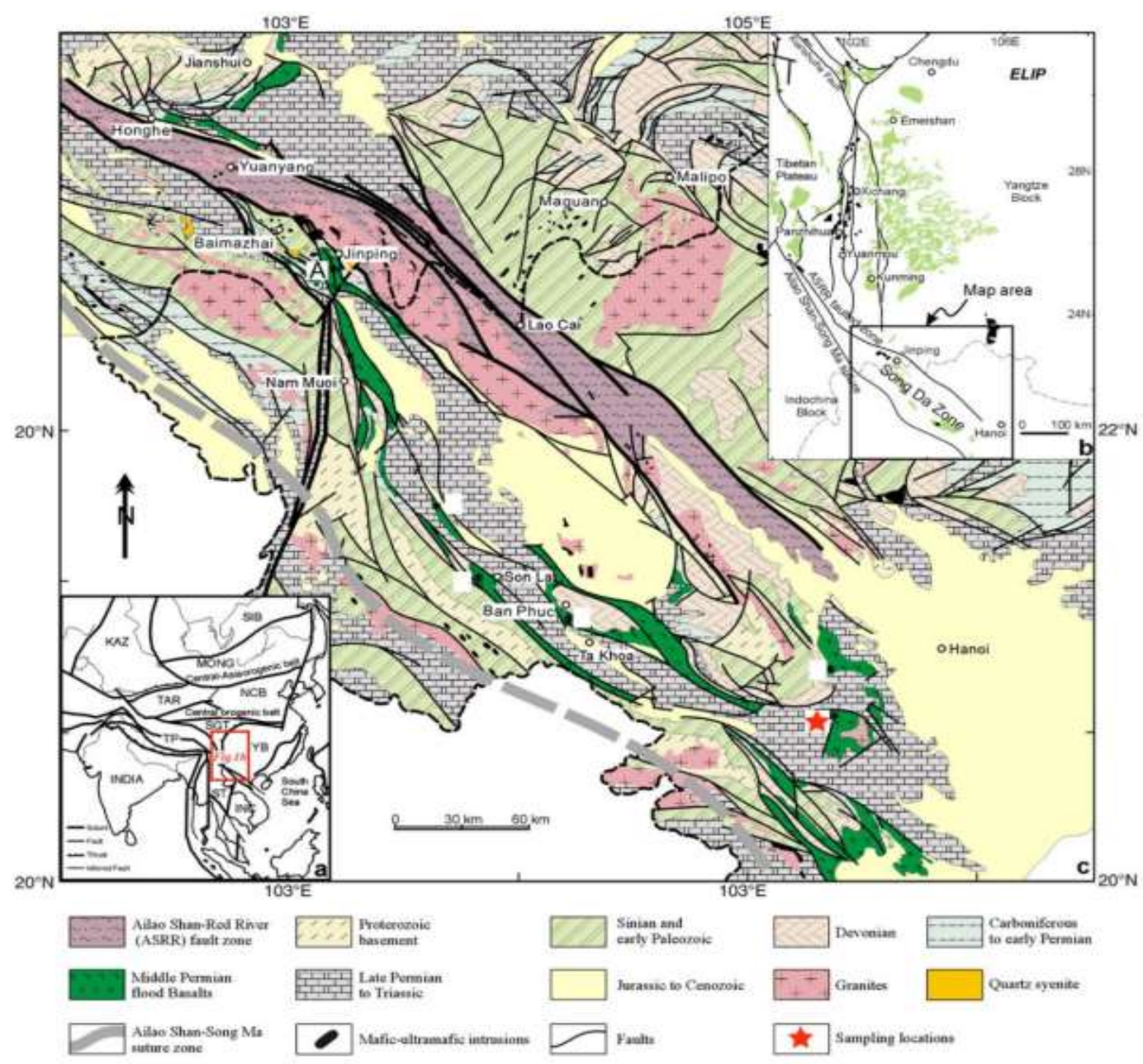

Figure 2. Geological sketch map of the NW Vietnam region showing the study area, modified from Wang et al. (2007). The major blocks shown in inset (a) are: SIB, Siberia; MONG, Mongolia; NCB, North China Block; YB, Yangtze Block; INC, Indochina Block; TAR, Tarim; KAZ, Kazakhstan; TP, Tibetan Plateau; SGT, Songpan-Ganze terrain; ST, Simao terrain. The Emeishan Large Igneous Province in SW China and northern Vietnam is shown in inset (b)

\section{Paleomagnetism and rock magnetism}

Individual specimens of $25 \mathrm{~mm}$ diameter and $22 \mathrm{~mm}$ in length were prepared from each sample in the laboratory. Natural remanent magnetizations (NRMs) were measured using a 2-G Enterprises three-axis, DC-SQUID pulse cooled cryogenic magnetometer. One specimen from each sample was subjected to stepwise thermal demagnetization up to $690^{\circ} \mathrm{C}$ using an ASC - TDS-48 thermal demagnetizer with a residual field below $5 \mathrm{nT}$. Another specimen of the same sample was 
Cung Thuong Chi, et al./Vietnam Journal of Earth Sciences 36 (2014)

subjected to stepwise alternating field (AF) demagnetization up to $100 \mathrm{mT}$ in order to choose the most effective demagnetization method for the rest of samples. Demagnetization results for each specimen were plotted on orthogonal vector diagrams (Zijderveld, 1967) to assess magnetization component structure as well as on equal-area projections to evaluate directional consistency. Principal component analysis (Kirschvink, 1980) was used to estimate component directions. Sitemean directions were calculated using Fisherian statistics (Fisher, 1953). The natural remanent magnetization intensity of basaltic rocks is varied, ranging from $0.045 \mathrm{~mA} / \mathrm{m}$ to $0.40 \mathrm{~A} / \mathrm{m}$. The samples with low NRM intensities show an unstable behavior during the thermal and alternating field (AF) demagnetizations (Fig. 3). Curves of bulk susceptibility vs. temperature show low Curie temperatures and alternating field demagnetization suggests that any magnetization is carried by high coercivity phases, thus suggesting goethite and pyrrhotite as likely contributors. The characteristic remanent magnetization (ChRM) components of these sample types, most likely, are of secondary origin. The higher NRM intensity samples have magnetite and hematite as the principal magnetic phases and show high Curie temperatures and laboratory unblocking temperatures $\left(\sim 580^{\circ} \mathrm{C}\right.$ for magnetite and $\sim 675^{\circ} \mathrm{C}$ for hematite) and consistent, if not very high quality behavior during progressive thermal and AF demagnetization (Fig. 4). The ChRM components are successfully isolated from the secondary components at about $450^{\circ} \mathrm{C}$ and/or 30 $\mathrm{mT}$ and uniformly decay toward the origin.
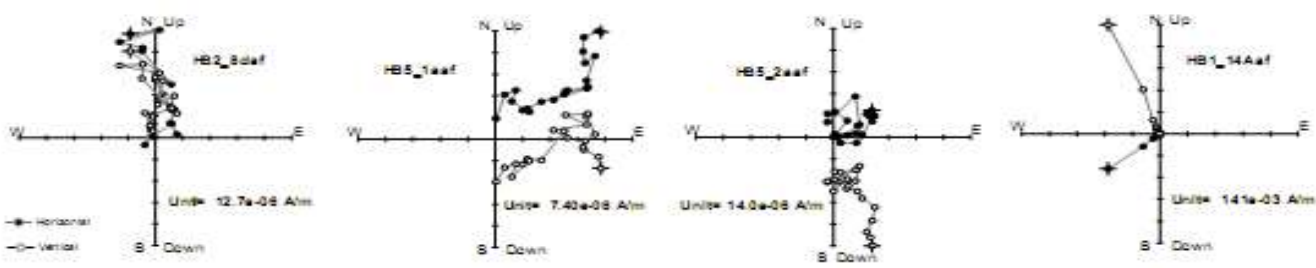

(a)

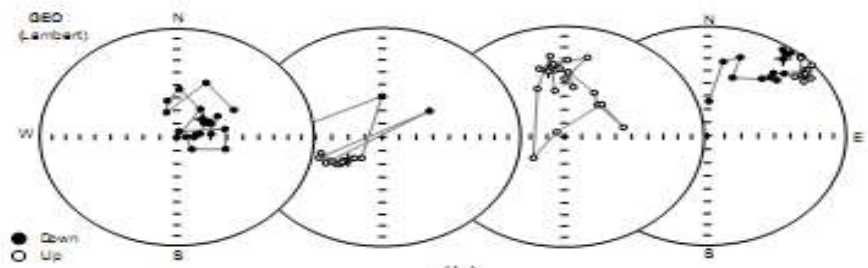

(b)
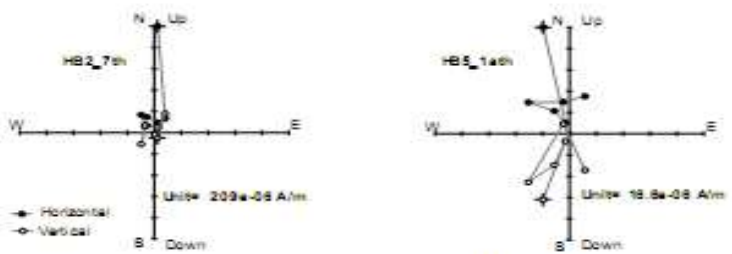

(d)

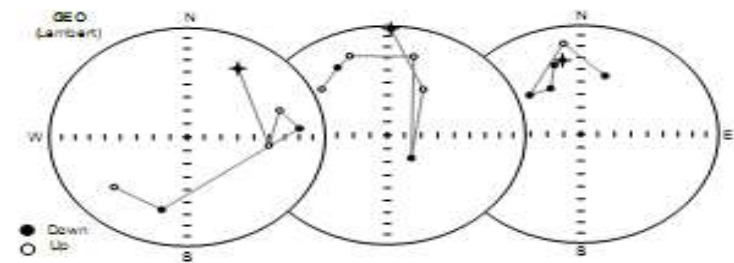

(e)

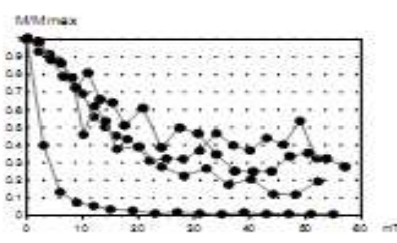

(c)
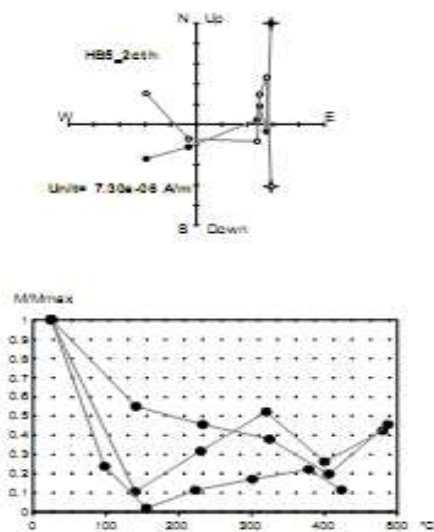

(f)

Figure 3. Representative thermal and AF demagnetization plots of weak-NRM samples. (a) \& (d): Zijderveld plots, (b) \& (e): stereographic plots, (c) \& (f): normalized magnetization plots 
Vietnam Journal of Earth Sciences 36 (2014) 413-423
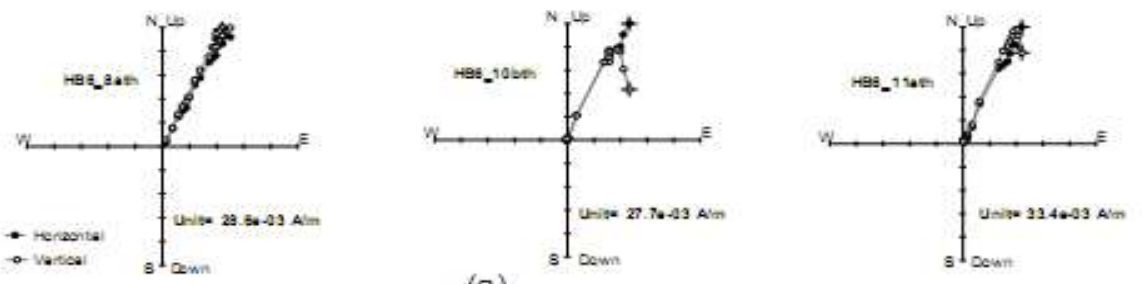

(a)

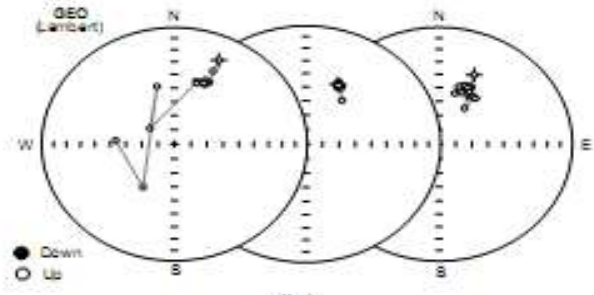

(b)
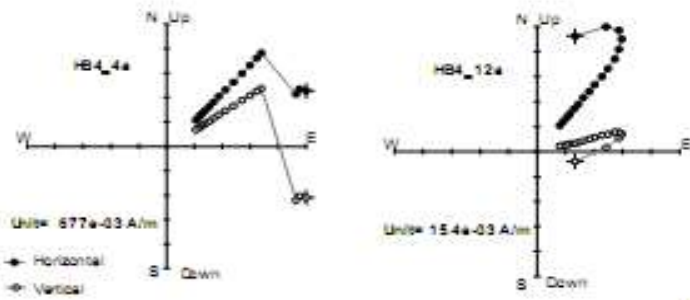

(d)
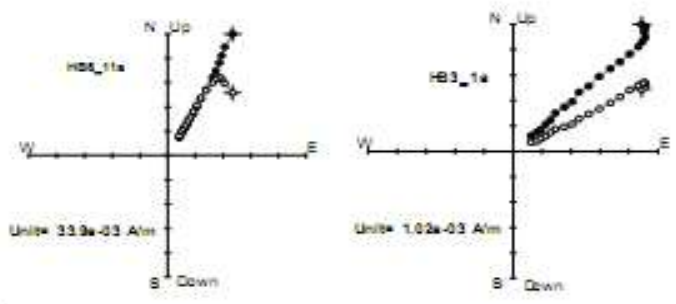

(c)

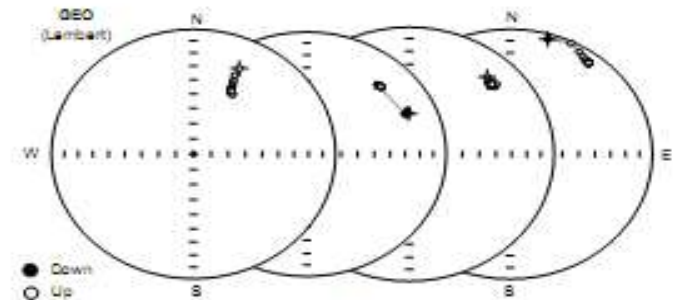

(e)

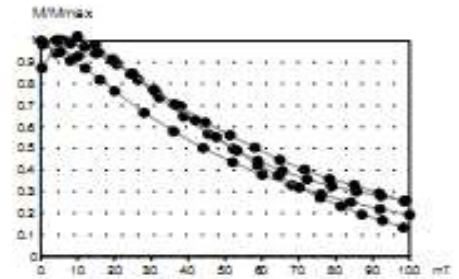

(f)

Figure 4. Representative thermal and AF demagnetization plots of strong-NRM samples. (a) \& (d): Zijderveld plots, (b) \& (e): stereographic plots, (c) \& (f): normalized magnetization plots

\section{Paleomagnetic results}

The site-mean directions of ChRM components are plotted on the Lambert equal-area projection together with the mean paleomagnetic direction of HoaBinh locality (Fig. 5) and their values are listed in Table 1. Except one site VN1 that has a positive inclination, the other nine sites possess a negative inclination. Their paleomagnetic directions are clearly different from the present geomagnetic direction of the study area as well as the paleomagnetic directions of younger rock formations in the northwestern Vietnam region (Cung et al., 2000b; Takemoto et al., 2005), which further corroborate their nature of primary NRM origin. The formation mean direction of 9 sites yields the values $\mathrm{D}_{\mathrm{g}}=33.8^{\circ}, \mathrm{I}_{\mathrm{g}}=-28.4^{\circ}, \alpha_{95}=9.5^{\circ}$, $\mathrm{k}=30.3$; corresponding to a virtual geomagnetic pole (VGP) located at $\lambda=41.1^{\circ} \mathrm{N}, \phi=239.8^{\circ} \mathrm{E}$. The paleopole position of HoaBinh basaltic rocks is basically indistinguishable from that of Permian Emeishan basalts in South China (Fig. 6). The similar paleopole positions of two distal basaltic 
Cung Thuong Chi, et al./Vietnam Journal of Earth Sciences 36 (2014)

rock formations from NW Vietnam and South China further corroborate the hypothesis of coeval time emplacement. The paleolatitude of the study area calculated from the formation mean direction is $\lambda_{\text {obs }}=-15.1^{\circ} \mathrm{N}$ (or $15.1^{\circ} \mathrm{S}$ ) indicating that the Hoa Binh basaltic rock formation was emplaced on the Earth surface during Late Permian - Early Triassic time at the southern hemisphere, near the equatorial region.

Using the mean paleopole of Upper Permian Lower Triassic volcanic and sedimentary rock formations from South China Block (Table 2), the expected paleomagnetic direction of Hoa Binh locality is computed and has the values: $\mathrm{D}_{\mathrm{ex}}=34.4^{\circ}$, $\mathrm{I}_{\mathrm{ex}}=-12.4^{\mathrm{o}}, \lambda_{\mathrm{ex}}=-6.3^{\circ} \mathrm{N}$. Using the paleopole of Upper Permian limestone formation from the Khorat Plateau reported by Yang and Besse (1993), the expected paleomagnetic direction of Hoa Binh locality is $\mathrm{D}_{\mathrm{ex}}=34.0^{\circ}, \mathrm{I}_{\mathrm{ex}}=46.2^{\circ}, \lambda_{\mathrm{ex}}=27.6^{\circ} \mathrm{N}$.

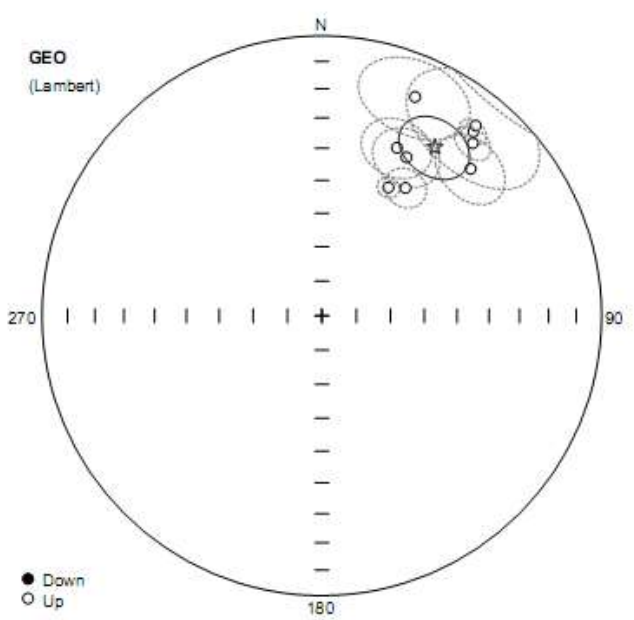

Figure 5. Lambert equal-area diagram showing the site mean directions and the mean direction of 9 sites with the ellipses of $95 \%$ confidence

Table 1. Paleomagnetic results of Late Permian-Early Triassic volcanic rocks from Hoa Binh Locality

\begin{tabular}{|c|c|c|c|c|c|c|c|c|c|c|c|c|c|c|c|}
\hline \multirow[t]{2}{*}{ Site } & \multicolumn{2}{|c|}{ Location } & \multirow{2}{*}{$\frac{\mathrm{Az} / \mathrm{Dp}}{(\mathrm{o})}$} & \multirow{2}{*}{$\mathrm{n} / \mathrm{N}$} & \multicolumn{6}{|c|}{ ChRM } & \multicolumn{2}{|c|}{ VGP } & \multirow{2}{*}{$\frac{d p}{(o)}$} & \multirow{2}{*}{$\frac{\mathrm{dm}}{(\mathrm{o})}$} & \multirow{2}{*}{$\frac{\lambda_{\text {paleo }}}{\left({ }^{\circ} \mathrm{N}\right)}$} \\
\hline & $\lambda\left({ }^{\circ} \mathrm{N}\right)$ & $\phi\left({ }^{\circ} \mathrm{E}\right)$ & & & $\mathrm{Dg}$ & Ig & Ds & Is & $\alpha_{95}$ & $\mathrm{k}$ & $\lambda\left({ }^{\circ} \mathrm{N}\right)$ & $\phi\left({ }^{\circ} \mathrm{E}\right)$ & & & \\
\hline HB 1-3 & 20.816 & 105.328 & - & $9 / 19$ & 23.1 & $\begin{array}{c}- \\
16.1\end{array}$ & - & - & 13.6 & 15.31 & 53.2 & 245.0 & 7.2 & 14 & -8.2 \\
\hline HB04 & 20.815 & 105.328 & - & $9 / 15$ & 39.5 & $\begin{array}{c}- \\
15.9\end{array}$ & - & - & 3.6 & 200.0 & 41.6 & 228.0 & 1.9 & 3.8 & -8.1 \\
\hline HB05 & 20.815 & 105.328 & - & $5 / 9$ & 39.0 & $\begin{array}{c}- \\
13.7\end{array}$ & - & - & 17.5 & 20.0 & 42.7 & 227.1 & 9.1 & 17.9 & -7.0 \\
\hline HB06 & 20.808 & 105.329 & - & $12 / 12$ & 27.4 & $\begin{array}{c}- \\
47.2\end{array}$ & - & - & 3.1 & 198.6 & 34.2 & 256.0 & 2.6 & 4.0 & -28.3 \\
\hline VN1* & 20.800 & 105.333 & - & $7 / 7$ & 33.5 & 43.7 & - & - & 7.8 & 60.5 & 59.1 & 181.2 & 6.1 & 9.7 & 25.5 \\
\hline VN2 & 20.800 & 105.333 & - & $7 / 7$ & 41.2 & $\begin{array}{c}- \\
19.2\end{array}$ & - & - & 4.9 & 155.1 & 38.9 & 229.1 & 2.7 & 5.1 & -9.9 \\
\hline VN3 & 20.800 & 105.333 & - & $7 / 7$ & 24.1 & 34.6 & - & - & 9.4 & 30.7 & 43.2 & 253.6 & 6.2 & 10.8 & -19.0 \\
\hline HOB1 & 20.800 & 105.333 & - & $6 / 10$ & 45.4 & $\begin{array}{c}- \\
26.2\end{array}$ & - & - & 9.9 & 50.8 & 33.2 & 229.8 & 5.8 & 10.7 & -13.8 \\
\hline HOB2 & 20.800 & 105.333 & - & $17 / 18$ & 28.1 & $\begin{array}{c}- \\
36.0\end{array}$ & - & - & 9.1 & 16.5 & 40.4 & 250.0 & 6.1 & 10.6 & -20.0 \\
\hline HOB3 & 20.800 & 105.333 & - & $21 / 21$ & 33.2 & 44.6 & - & - & 5.9 & 29.7 & 32.6 & 249.9 & 4.7 & 7.4 & -26.2 \\
\hline $\begin{array}{c}\text { Mean } \\
\mathrm{G}\end{array}$ & 20.805 & 105.331 & - & $9 / 10$ & 33.8 & $\begin{array}{c}- \\
28.4 \\
\end{array}$ & - & - & 9.5 & 30.3 & 41.1 & 239.8 & 5.7 & 10.4 & -15.1 \\
\hline
\end{tabular}

Note: (*) - sites are excluded from the calculation of site mean; Az/Dp: Azimuth of dip/Dip; ChRM: characteristic remanent magnetization; VGP: Virtual geomagnetic pole; $\lambda_{\text {paleo }}$ Paleolatitude of the site. Sites from VN1 to HOB3 from Cung et al. (2000b) 
Vietnam Journal of Earth Sciences 36 (2014) 413-423

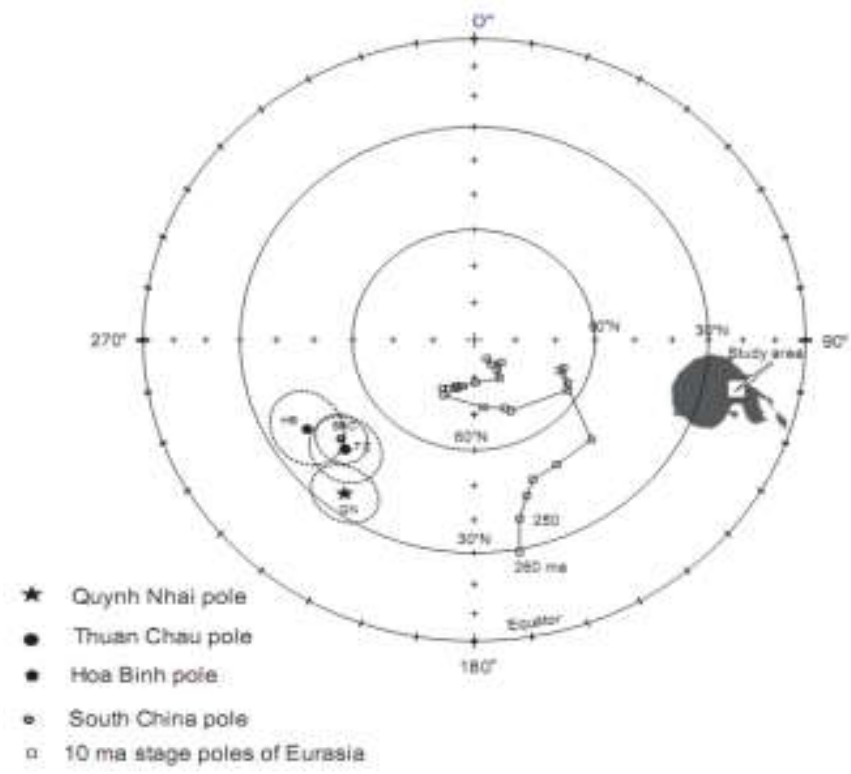

Figure 6. Equal-area diagram showing the position of VGP pole of Hoa Binh locality relative to coeval paleopoles of Thuan Chau, Quynh Nhai areas and the South China Block, and the APWP of Eurasia

Table 2. Late Permian-Early Triassic virtual geomagnetic poles from South China and Indochina

\begin{tabular}{|c|c|c|c|c|c|c|c|}
\hline \multirow[t]{2}{*}{ Age } & \multirow{2}{*}{$\frac{\text { Locality }}{\lambda}$} & \multirow{2}{*}{$\frac{\text { VGP coord. }}{\phi}$} & \multirow{2}{*}{$\frac{\mathrm{A}_{95}}{\lambda}$} & \multirow{2}{*}{\multicolumn{2}{|c|}{$\frac{\text { Rock type }}{\phi}$}} & \multirow[t]{2}{*}{ Reference } & \\
\hline & & & & & & & \\
\hline \multicolumn{8}{|c|}{ South China Block: } \\
\hline $\mathrm{P} 2$ & 29.6 & 103.4 & 52.7 & 252.1 & 6.0 & $\begin{array}{l}\text { Basalt and red sandstone } \\
\text { (Emeishan, Sichuan) }\end{array}$ & McEnhinny et al., 1981 \\
\hline $\mathrm{P} 2$ & 29.6 & 103.4 & 49.7 & 252.0 & 2.8 & Emeishan basalt & Zhao and Coe, 1989 \\
\hline $\mathrm{P} 2$ & 29.6 & 103.4 & 54.1 & 241.8 & 19.0 & $\begin{array}{l}\text { Basalt and limestone } \\
\text { (Emeishan, Sichuan) }\end{array}$ & Chan et al., 1984 \\
\hline $\mathrm{P} 2$ & 29.6 & 103.5 & 38.5 & 231.6 & 4.9 & Emeishan basalt, Xihekou & Liu et al., 1985 \\
\hline $\mathrm{P} 2$ & 28.1 & 102.9 & 58.9 & 246.1 & 6.6 & Basalt, Zhaojue, Sichuan & Liu et al., 1985 \\
\hline $\mathrm{P} 2$ & 27.6 & 101.9 & 63.5 & 264.3 & 9.8 & Basalt, Yanguan, Sichuan & Liu et al., 1985 \\
\hline P2 & 28.3 & 103.0 & 54.3 & 251.2 & 20.0 & Basalt, Meigou, Sichuan & Zhou et al., 1986 \\
\hline $\mathrm{P} 2$ & 26.8 & 101.8 & 25.6 & 216.4 & 12.6 & Basalt, Miyi, Sichuan & Zhou et al., 1986 \\
\hline $\mathrm{P} 2$ & 26.7 & 102.9 & 53.5 & 241.8 & 10.1 & Basalt, Huidong, Sichuan & Huang et al., 1986 \\
\hline $\mathrm{P} 2$ & 26.1 & 103.1 & 52.5 & 226.0 & 25.0 & Basalt, Dongchuan, Yunnan & Huang et al., 1986 \\
\hline $\mathrm{P} 2$ & 25.9 & 100.6 & 24.7 & 204.3 & 24.8 & Basalt, Binhchuan, Yunnan & Huang et al., 1986 \\
\hline $\mathrm{P} 2$ & 26.4 & 105.7 & 29.3 & 235.3 & 13.4 & Basalt, Xiongjiachang, Guizhou & Lin, 1984 \\
\hline $\mathrm{P} 2$ & 25.6 & 103.0 & 50.0 & 241.0 & 6.1 & Basalt, Kunming, Yunnan & Fang and Vander Voo, 1990 \\
\hline $\mathrm{P} 2-\mathrm{T} 1$ & 32.4 & 105.5 & 47.2 & 226.3 & 4.2 & Red limestone, Guanyuan, Sichuan & Steiner et al., 1989 \\
\hline $\mathrm{P} 2-\mathrm{T} 1$ & 32.4 & 105.5 & 47.9 & 225.1 & 5.4 & Red limestone, Guanyuan, Sichuan & Heller et al., 1988 \\
\hline $\mathrm{P} 2-\mathrm{T} 1$ & 30.0 & 106.3 & 38.5 & 209.8 & 3.3 & Red limestone, Hechuan, Sichuan & Steiner et al., 1989 \\
\hline $\mathrm{P} 2-\mathrm{T} 1$ & 29.6 & 105.6 & 45.8 & 225.2 & 7.0 & Red limestone, Chongqing, Sichuan & Steiner et al., 1989 \\
\hline $\mathrm{P} 2-\mathrm{T} 1$ & 30.0 & 107.0 & 39.8 & 216.2 & 5.3 & Red limestone, Changshou, Sichuan & Enkin, 1990 \\
\hline P3-T1 & 29.5 & 106.0 & 40.7 & 215.0 & 6.8 & Sichuan & Enkin et al., $1992 \mathrm{~b}$ \\
\hline Mean: & 28.6 & 103.9 & 46.8 & 230.4 & 6.5 & & \\
\hline \multicolumn{8}{|c|}{ Indochina Block: } \\
\hline $\mathrm{P} 2$ & 16.7 & 101.8 & 58.4 & 176.2 & 7.2 & $\begin{array}{l}\text { Limestone, Khorat Plateau, Thailand } \\
\text { Yang and Bese, } 1993\end{array}$ & \\
\hline $\mathrm{P} 2$ & 20.8 & 105.3 & 41.1 & 239.8 & 9.5 & Basalt, Hoa Binh, NW Vietnam & This study \\
\hline
\end{tabular}


Cung Thuong Chi, et al./Vietnam Journal of Earth Sciences 36 (2014)

\section{Discussion}

On the basis of biogeographic and paleomagnetic data, palaeogeographic reconstruction models of Permian eastern Pangea and Tethys have been proposed by different workers (Sengor, 1979, 1984, 1988, 1989; Hutchison, 1989; Gatinsky and Hutchison, 1986; Metcalfe, 1988, 1991, 1996, 2002; Scotese et al., 1992, 1995; Dercourt et al., 1993; Ziegler et al., 1997; Zonenshain et al., 1985; Li et al., 1993; Li and Powell, 2001). All of the reconstruction models broadly agree on the reconstruction of the principal components of Pangea.

The continental core of mainland Southeast Asia comprises the Sibumasu, Indochina and South China blocks and the Sukhothai island Arc terrane, located between Sibumasu and South China/Indochina (Sone and Metcalfe, 2008; Metcalfe, 2012). Most models for the position of South China during the Permian have the subcontinent situated on, or slightly south of the equator and slightly counter-clockwise rotated; this configuration has been supported by paleomagnetic, biogeographic and climatic data and it did not experience significant latitudinal displacement during the Permian. The position of the Indochina Block, however, is somewhat in dispute. Scotese and McKerrow (1990) and Metcalfe (1998, 2002) and Li and Powell (2001) position Indochina and South China together, welded along the Song Ma Suture Zone during Late Devonian-Early Carboniferous and forming the South China- Indochina Super-terrain during the Permian, characterized by Tethyan fauna and Cathaysian flora. Ziegler et al. (1997, 1998), on the other hand, argue that these terranes remain separated during the Permian.

According to the paleogeographic reconstruction models, the northwestern Vietnam, in general, and the Hoa Binh locality, in particular, belongs to the South China Block but not to the ancient Indochina Block as described by Metcalfe $(2011,2012)$ because the Song Ma Suture situates to the southwest of this region. Based on this reason, it is improperly to use the paleopole of Upper Permian limestone formation from the Khorat Plateau reported by Yang and Besse (1993) for calculating the expected paleomagnetic direction of the Hoa Binh area. The rotation and latitudinal translation of Hoa Binh locality relative to the South China Block are calculated and have the values as follow: $\mathrm{R}=0.5^{\circ} \pm 9.5^{\circ}, \mathrm{d}=8.8^{\circ}$ $\pm 9.2^{\circ}$; which are statistically insignificant indicating that the Hoa Binh locality has been relatively stable with respect to the South China Block since the Late Permian - Early Triassic time. The stable position of Hoa Binh area with respect to the South China Block deduced from the paleomagnetic results of this study is consistent with that of Late Permian basaltic formations from Son La area (Cung et al., 2015, in press) and also consistent with that of Cretaceous red-bed formations from NW Vietnam region reported by Cung et al. (2000b) and Takemoto et al. (2005).

The consistency of paleomagnetic information on relative tectonic displacement of northwestern Vietnam region obtained from different rock formations with different geological ages shows that this region has been a coherent part of the South China Block during the Mesozoic time to present and also reveals a minor (or insignificant) role of the Red River fault played during the Cenozoic time relating to the India-Eurasia collision.

\section{Conclusions}

a/ The Hoa Binh locality, in particular, and the northwestern Vietnam region, in general, has been a coherent part of the South China Block and situated near the Equator during the Late Permian Early Triassic time.

b/ The Red River fault has played a minor role during the Cenozoic India-Eurasia collision and there has occurred a minor (or insignificant) tectonic displacement along this fault in terms of paleomagnetism.

c/ If the Indochina Block had been indeed extruded southward during the India-Eurasia collision, this motion would be occurred along some other faults located to the south of the study area.

\section{Acknowledgements}

This research has been supported by a grant for the basicresearch project (No.105.04-2011.24) from National Foundation for Science and Technology Development (NAFOSTED) of 
Vietnam Journal of Earth Sciences 36 (2014) 413-423

Vietnam to Cung Thuong Chi. Part of Geissman's travel support and paleomagnetic measurements were provided by the University of Texas Stars Program.

\section{References}

Achache, J., Courtillot, V., 1985: A preliminary Upper Triassic paleomagnetic pole for the Khorat Plateau (Thailand): Consequences for the accretion of Indochina against Eurasia.Earth Planet. Sci. Lett., 73, 147-157.

Cai, J.-X., Zhang, K.J., 2009: A new model for the Indochina and South China collision during the Late Permian to the Middle Triassic. Tectonophysics 467, 35-43.

Chan, L.S., Wang, C.Y., Wu, X.Y., 1984: Paleomagnetic results from some Permian-Triassic rocks from southwestern China. Geophys. Res. Lett., 11, 11, $1157-1160$.

Chen, Y., Courtillot, V., 1989: Widespread Cenozoic (?) remagnetization in Thailand and its implications for IndiaAsia collision. Earth Planet. Sci. Lett., 93, 113-122.

CungThuong Chi, 1996: Paleomagnetism of Mesozoic and Cenozoic rocks from Vietnam: Implications for the Tertiary tectonic history of Indochina and a test of the extrusion model. Ph.D. Dissertation, 228pp., Texas A\&M University, College Station, Texas, USA.

Cung Thuong Chi, Nguyen Quoc Cuong, Nguyen Trong Yem, 2000a: Preliminary paleomagnetic results of Late PermianEarly Triassic basalts from northwestern Vietnam and their tectonic implications. Journal of Geology, A/259, 7-8/2000, 1-8. (In Vietnamese)

Cung Thuong Chi, Nguyen Trong Yem, Nguyen Quoc Cuong, 2000b: Paleomagnetic study on Late Jurassic-Cretaceous extrusive and intrusive rocks from northwestern Vietnam. Journal of Geology, A/256, 1-2/2000, 1-8. (In Vietnamese).

Dercourt, J., Ricou, L.E., Vrielynck, B. (Eds.), 1993 : Atlas Tethys Palaeoenvironmental Maps Gauthier-Villars, Paris 307pp., 14 maps, 1 plate.

Enkin, R.J., 1990: Formation et deformation de l'Asie depuis la fin de l'ere primaire: les apports de l'etudepaleomagnetique des formations secondaires de Chine du Sud. Ph.D. Thesis, 333 pp., Univ. de Paris 7.

Enkin, R.J., Yang, Z., Chen, Y., Courtillot, V., 1992b: Paleomagnetic constraints on the geodynamic history of the major blocks of China from the Permian to the present. J. Geophys. Res., 97, B10, 13,953-13,989.
Fang, W., Van Der Voo, R., 1990: Paleomagnetism of the Late Permian Emeishan basalt, Yunnan, China. Eos Trans. AGU, 71, 488.

Fisher, R.A., 1953: Dispersion on a sphere. Proc. Roy. Soc. London, Series A, 217, 295-305.

Gatinsky, Y.G., Hutchinson, C.S., 1986: Cathaysia, Gondwanaland and the Palaeotethys in the evolution of continental Southeast Asia. Proceed. GeoSea V Congress, Geol. Soc. Malaysia Bull., 20.

Glotov, A.I., Polyakov, G.V., Hoa, T.T., Balykin, P.A., Akimtsev, V.A., Krivenko, A.P., Tolstykh, N.D., Phuong, N.T., Thanh, H.H., Hung, T.Q., Petrova, T.E., 2001: The Ban Phuc Ni-Cu-PGE deposit related to the Phanerozoic komatiite-basalt association in the Song $\mathrm{Da}$ rift, northwestern Vietnam. Can. Mineral.39, 573-589.

Hanski, E., Walker, R.J., Huhma, H., Polyakov, G.V., Balykin, P.A., Tran, Trong Hoa, Ngo, Thi Phuong, 2004: Origin of the Permian-Triassic komatiites, northwestern Vietnam. Contributions to Mineralogy and Petrology 147, 453-469.

Heller, F., Lowrie, W., Li, H., Wang, J., 1988: Magnetostratigraphy of the Permo-Triassic boundary section at Shangsi (Guanggyuan, Sichuan, China). Earth Planet. Sci. Lett., 88, 348-356.

Huang, K., Opdyke, N., Kent, D., Xu, G., Tang, R., 1986: Further paleomagnetic results from the Permian Emeishan basalts in SW China (in Chinese). KexueTongbao, 31, 1192-1201.

Hutchinson, C.S., 1989: The palaeo-Tethyan realm and Indosinian orogenic system of Southeast Asia. In: Sengor, A.M.C. (Ed.). Tectonic Evolution of the Tethyan Region, 585-643, Academic San Diego, California, 1989b.

Kirschvink, J.L., 1980: The least-square line and plane and the analysis of paleomagnetic data. Geophys. J. R. Astron. Soc. London, 62, 699-718.

Lacassin, R., Leloup, P.H., Trinh, P.T., Tapponnier, P., 1998: Unconformity of red sandstones in north Vietnam: field evidence for Indosinian orogeny in northern Indochina? Terra Nova 10, 106-111.

Lepvrier, C., Maluski, H., Vu Van Tich, Leyreloup, A., Phan Truong Thi, Nguyen Van Vuong, 2004: The Early Triassic Indosinian orogeny in Vietnam (Truong Son Belt and Kontum Massif); implications for the geodynamic evolution of Indochina. Tectonophysics 393, 87-118.

Lepvrier, C., Nguyen Van Vuong, Maluski, H., Phan Truong Thi, Tich Van Vu, 2008: Indosinian tectonics in Vietnam. C. R. Geoscience 340, 94-111. 


\section{Cung Thuong Chi, et al./Vietnam Journal of Earth Sciences 36 (2014)}

Li, Z.X., Powell, CMcA., 2001: An outline of the palaeogeographic evolution of the Australian region since the beginning of the Neoproterozoic. Earth Science Reviews 53, 237-277.

Li, Z.X., Zhang, I., Powell, C.McA., Trench, A., 1993: Palaeozoic global reconstructions, In: Long, J.A. (Ed.). Palaeozoic Vertebrate Biostratigraphy and Biogeography. Belhaven Press, London, pp. 25-53.

Lin, J.L., 1984: The apparent polar wonder paths for the North and South China blocks. Ph.D. Thesis, 248 pp. Univ. of California, Santa Barbara.

Liu, C., Zhu, R., Jing, Z., 1985: Paleomagnetic study of Late Permian Emeishan basalts from Panxi and its neighbouring areas (in Chinese). In: Contributions to Panxi rift, China, Vol. 2, edited by Y. Zhang, pp. 194-200, Geological Publishing House, Beijing.

McElhinny, M.W., 1981: Fragmentation of Asia in the Permian. Nature 293, 212-216.

Metcalfe, I., 1988: Origin and assembly of Southeast Asia continental terranes, Gondwana and Tethys, In: AudleyCharles, M.G., Hallam, A. (Eds.). Geological Society of London Special Publication 37, 101-118.

Metcalfe, I., 1991: Late Palaeozoic and Mesozoic palaeogeography of Southeast Asia. Palaeogeography, Palaeoclimatology, Palaeoecology 87, 211-221.

Metcalfe, I., 1996: Pre-Cretaceous evolution of SE Asian terranes. In: Hall, R., Blundell, D. (Eds.). Tectonic Evolution of Southeast Asia. Geological Society of London Special Publication 106, 97-122.

Metcalfe, I., 1998: Palaeozoic and Mesozoic geological evolution of the SE Asian region, multidisciplinary constraints and implications for biogeography. In: Hall, R., Holloway, J.D. (Eds.). Biogeography and Geological Evolution of SE Asia. Backhuys Publishers, Amsterdam, pp. $25-41$

Metcalfe, I., 2002: Permian tectonic framework and palaeogeography of SE Asia. Journal of Asian Earth Sciences 20, 551- 566 .

Metcalfe, I., 2011: Tectonic framework and Phanerozoic evolution of Sundaland. Gondwana Research 19, 3-21.

Metcalfe, I., 2012: Changhsingian (Late Permian) conodonts from Son La, northwest Vietnam and their stratigraphic and tectonic implications. Journal of Asian Earth Sciences 50, 141-149.

Phan $\mathrm{Cu}$ Tien, 1977: Late Permian-Early Triassic sediments from northwestern Vietnam. In: The geological problems of NW Vietnam region, Science and Technique Publisher House, Hanoi, pp.109-151. (In Vietnamese).

Polyakov, G.V., Tran Trong Hoa, Akimtsev, V.A., Balykin, P.A., Ngo Thi Phuong, Hoang Huu Thanh, Tran Quoc Hung, Bui An Nien, Tolstykh, N.D., Glotov, A.I., Petrova, T.E., Vu Van Van, 1999: Ore and geochemical specialization of Permo-Triassic ultramafic-mafic complexes in North Vietnam. Geologiya i Geofizika (Russian Geology and Geophysics) 40 (10), 1474-1487 (1453-1467).

Sengor, A.M.C., 1979: Mid-Mesozoic closure of PermoTriassic Tethys and its implications. Nature 279, 590-593.

Sengor, A.M.C., 1984: The Cimmerideorogenic system and the tectonics of Eurasia. Geological Society of America Special Paper 195, 82.

Sengor, A.M.C., 1987: Tectonic subdivisions and evolution of Asia. Bulletin of the Technical University of Istanbul 40, 355-435.

Sengor, A.M.C., 1989: The TethysideOrogenic System, an introduction, In: Sengor, A.M.C. (Ed.). Tectonic Evolution of the Tethyan Region. Kluwer, Dordrecht, pp. 1-22.

Scotese, C.R., McKerrow, W.S., 1990: Revised world maps and introduction. In: McKerrow, W.S., Scotese, C.R. (Eds). PalaeozoicPalaeogeography and Biogeography. Geological Society Memoir 12, 1-21.

Scotese, C.R., Golonka, J., 1992: Paleogeographic Atlas.Paleomap Progress Report 20-0692. Department of Geology, University of Texas at Arlington, 34pp.

Scotese, C.R., Langford, R.P., 1995: Pangea and the paleogeography of the Permian. In: Scholle, P.A., Peryt, T.M., Ulmer-Scholle, D.S. (Eds.). The Permian of northern Pangea. Paleogeography, Paleoclimate and Stratigraphy, Vol. 1, Springer, Berlin, pp. 3-19.

Sone, M., Metcalfe, I., 2008: Parallel Tethyan Sutures in mainland SE Asia: new insights for Palaeo-Tethys closure. Compte Rendus Geoscience 340, 166-179.

Steiner, M., Ogg, J., Zhang, Z., Sun, S., 1989: The Late Permian -Early Triassic magnetic polarity time scale and plate motion of South China. J. Geophys Res., 94, 7343-7363.

Takemoto, K., Halim, N., Otofuji, Y., Tran Van Tri, Le Van De, Hada, S., 2005: New paleomagnetic constraints on the extrusion of Indochina: Late Cretaceous results from the Song Da terrane, northern Vietnam. Earth. Planet. Sci. Lett., 229, 273-285.

Tran Trong Hoa, 1996: Magmatic activities of Northwestern Truong Son belt in Mesozoic-Cenozoic. Material 


\section{Vietnam Journal of Earth Sciences 36 (2014) 413-423}

substances, forming conditions and mineral resource potential // J. Sci Earth. 18 (3), 218-227.

Tran Trong Hoa, 2001: Division and Comparison of PermianTriassic basaltoid complex of the Song Da zone. Journal of Geology A/265, 12-19, Hanoi, Vietnam (In Vietnamese).

Van Der Voo, R., Fang, W., Wang, Z., Suk, D., Peacor, R., Liang, Q., 1993: Paleomagnetism and electron microscopy of the Emeishan basalts, Yunnan, China. Tectonophysics 221, 367-379.

Yang, Z., Besse, J., 1993: Paleomagnetic study of Permian and Mesozoic sedimentary rocks from northern Thailand supports the extrusion model for Indochina. Earth Planet. Sci. Lett., 117, 525-552.

Zhang, K.J., Cai, J.-X., 2009: NE-SW-trending Hepu-Hetai dextral shear zone in southern China: penetration of the Yunkai Promontory of South China into Indochina. Journal of Structural Geology 31, 737-748.

Zhang, K.J., Cai, J.-X., Zhu, J.-X., 2006: North China and South China collision: insights from analogue modeling. Journal of Geodynamics 42, 38-51.

Zhao, X.X., Coe, R.S., 1987: Palaeomagnetic constraints on the collision and rotation of North and South China. Nature $327,141-144$
Zhou, M.F., Arndt, N.T., Malpas, J., Wang, C.Y., Kennedy, A.K., 2008: Two magmaseries and associated ore deposit types in the Permian Emeishan large igneous province, SW China. Lithos 103, 352-368.

Zhou, Y., Lu, L., and Zheng, B., 1986: Paleomagnetic polarity of the Permian Emeishan basalt in Sichuan (in Chinese). Geol. Rev., 32, 465-469.

Ziegler, A.M., Hulver, M.L., Rowley, D.B., 1997: Permian World Topography and Climate, In: Martinin, I.P. (Ed.). Late Glacial and Postglacial Environmental Changes.Oxford University Press, New York, pp.111-146.

Ziegler, A.M., Gibbs, M.T., Hulver, M.L., 1998: A mini-atlas of oceanic water masses in the Permian Period. Proceedings Royal Society of Victoria 110, 323-343.

Zijderveld, J.D.A., 1967: A.C. demagnetization of rocks: Analysis of results, In: Methods in paleomagnetism, edited by D.W. Collinson, K.M. Creer, and S.K. Runcon, 254286, Elsevier, New York.

Zonenshain, L.P., Kuzmin, M.I., Kononov, M.V., 1985: Absolute reconstructions of the Palaeozoic oceans. Earth and Planetary Science Letters 74, 103-116. 